Volume 7 Issue 2, June 2020

Nationally Accredited Journal,

Decree No. B/4130/E5/E5.2.1/2019

\title{
Law Due To The Transfer Of Land Under Hand With Deed As Evidence (Case Study In Kendari)
}

\section{Steffi Yesyer Palloan ${ }^{1}$}

Abstract. The purpose of this study as follows 1) To identify and explain the legal effect on the transition of land right under the deed of hand as evidence. 2) To identify and explain the weaknesses of the transitional land right under the deed of hand. 3) To identify and explain the transfer of land rights solutions with deed under the hand. The method used by researchers is approach to law juridical sociological and specification in this study were included descriptive analysis. The sources and types of data in this study are primary data obtained from field studies with interviews with the Notary in Kendari. And secondary data obtained from the study of literature. Based on the results of research The absence of legal certainty for those who receive the new rights over the land in question, as for a way to resolve that can be achieved is by registering the transfer of land rights to the Land Office. Many people who do not register the transfer of rights or title transfer to the Land Office is the lack of information about the process of the registration of the land, there are many people who make the switch right to the land under the hand not in front of PPAT, economic factors, the cost of registration of transfer of rights is fairly high and not transparent and there are still many who do not own land Earth Building Tax. Direct settlement by parties with deliberation. Through arbitration and alternative dispute resolution. Judicial dispute resolution

Keywords: Transfer of Rights to Land; Under Hands Deed; Evidence.

\section{Introduction}

Soil is a natural resource for human life and is one of Indonesia's wealth that has a very important social function for the people of Indonesia to improve the prosperity and welfare. So that the designation should be established and governed by the laws. In Act 1945, Article 33 paragraph (3) has stated that the land and water and natural resources contained therein controlled by the state and utilized for the welfare of the people.

Increasing number of people who need land for housing, as well as the progress and development of the economic, socio-cultural and technological willed also the availability of land lots, for example for plantations, farms, factories, offices, entertainment venues and roads for transportation. ${ }^{2}$

Therefore, it is composed of Law No. 5 of 1960 About the Basic Regulation of Agrarian. One of the objectives of the Basic Agrarian Law (BAL) is to provide legal certainty with regard to the rights of the land held by the public. To achieve these objectives, the government held land registration, and expressly provided for in Article 19 paragraph (1) BAL stating that to ensure legal certainty, the Government

\footnotetext{
${ }^{1}$ Student Master of Notary Program (Mkn) Sultan Agung Islamic University, Semarang, email: yesyersteffi@gmail.com

${ }^{2}$ Wantjik Saleh, 1997, Hak Anda atas Tanah, Jakarta: Ghalia Indonesia, p. 7.
} 
held land registration throughout the territory of the Republic of Indonesia in accordance with the provisions stipulated in Government Regulation. ${ }^{3}$

PPAT deed is a deed is authentic, this was confirmed by Article 1 (1) and Article 3 (1) of Government Regulation No. 37 of 1998 on the Regulation of Land Deed Official Position. As an authentic deed, against PPAT deed of the provisions concerning the terms and procedures for the manufacture of an authentic deed. Authentic deed form determined by law, while officials may make it unavoidable that weighs the same shall be determined by the laws or regulations on par with the legislation. ${ }^{4}$

PPAT Deed serves as proof of the correct tool is already doing selling. Sale and purchase can still be proved by other means of proof. But in a land registration system in accordance with Government Regulation No. 24 of 1997 on Land Registration, registration and selling it can only be done with PPAT deed as proof. The person doing the selling without proven by PPAT deed will not be able to obtain a certificate, although sales of its purchasing lawful. ${ }^{5}$

Transfer of rights on land that is not carried out in the presence of PPAT is no sanction for the parties, but the parties will meet the practical difficulties of the assignee, will not be able to register transfer of rights so it will not get a certificate on his behalf. Therefore, the path that can be taken is to repeat the procedure right in front of PPAT transition. ${ }^{6}$

Based on the above problems, the purpose of this study as follows: To identify and explain the legal effect on the transition of land right under the deed of hand as evidence; To identify and explain the weaknesses of the transitional land right under the deed of hand; and To identify and explain the transfer of land rights solutions with deed under the hand.

\section{Research methods}

In this study the juridical sociological research methods used by the author is the case study method. Type of study in this research is descriptive research which is intended to gather information about the status or existing symptoms, the symptoms according to what their circumstances at the time of the study. ${ }^{7}$ This study intends to describe the data clearly on the object under study. The sources and types of data in this study are primary data obtained from field studies with interviews with the Notary in Kendari. And secondary data obtained from the study of literature.

\footnotetext{
3 Boedi Harsono, 2008, Hukum Agraia Indonesia, Sejarah Pembentukan Undang-Undang Pokok Agraria, Isi dan Pelasanaannya, Jakarta: Djambatan, p. 471

${ }^{4}$ Herlien Budiono, 2007, Kumpulan Tulisan Hukum Perdata di Bidang Kenotariatan, Bandung: Citra Aditya Bakti, p. 59.

${ }^{5}$ Effendi Perangin, 1994, Hukum Agraria Indonesia, Suatu Telaah Dari Sudut Pandang Praktisi Hukum, Jakarta: King Grafindo Persada, p. 15.

${ }^{6}$ J. Kartini Soedjendro, 2001, Perjanjian Peralihan Hak Atas Tanah Yang Berpotensi Konflik, Yogyakarta: Kanisius, p. 73

${ }^{7}$ Suharsimi Arikunto, 1990, Manajemen Penelitian, Jakarta: Rineka Cipta, p. 309
} 
Volume 7 Issue 2, June 2020

Nationally Accredited Journal, Decree No. B/4130/E5/E5.2.1/2019

\section{Discussion}

\subsection{Transition Effects Over Land Rights Under the Deed Hand As Evidence in Kendari}

The transition of land rights is to move or shift control of land that originally belonged to a person or a group of other civic society. A land rights would switch if its ownership passed to others through a legal act, but switched as a result of a particular legal act, for example due to a death or the death of someone then switched wealth legacy to his heir. Transfer of ownership of a plot of land to a new owner because of something or a certain legal actions. Legal actions can be defined as any act committed by a natural person who creates legal effect. According to CST Kansil, that "all legal actions of man who deliberately committed by a person to cause the rights and obligations, such as wills, ${ }^{8}$ Legal act that consists of:

- Unilateral legal acts, namely the legal act performed by a single party and blow up the rights and obligations of the parties as well, such a legal act of wills, and the gift giver something (an object).

- Legal acts of two parties, is a legal act carried out by the two parties and give rise to rights and obligations for both parties (reciprocity), sale and purchase agreements, leasing and others.

Proof of ownership that basically consists of a proof of ownership on behalf of rights holders at the time of entry into force of the BAL and if such rights then switch evidence consecutive transfer of rights to the hands of rights holders at the right time to do the bookkeeping. In the juridical data collection activities conducted evidentiary differences between new rights and the right time. New rights are granted or created a new one since the entry into force of Government Regulation No. 24 of 1997.

Written evidence that is meant to be:

- Grosse eigendom rights certificates issued by Overschrijvings Ordinance (S.183427), which had been spiked with a note, that the rights concerned eigendom converted into property rights; or

- Grosse eigendom rights certificates issued by Overschrijvings Ordinance (S.183427) since the entry into force of the BAL until the date of registration of land held under Government Regulation No. 10 of 1961 in the regions concerned; or

- Letter proof of property rights issued pursuant to Rule Swapraja concerned; or

- Property right certificate issued by the Minister of Agrarian Regulation No. 9 of 1959; or

- A decree granting property rights of official air-treatment, either before or since the enactment of the BAL, which is not accompanied by an obligation to register the rights granted, but have met all the obligations referred to therein; or

- Deed of transfer of rights created under the hand that bore the testimony by the Customary Chief / Head of Village / Village created before the enactment of this Government Regulation; or

- Deed of transfer of land made by PPAT, whose land has not been recorded; or

${ }^{8}$ CST Kansil, 1986, Pengantar IImu Hukum dan Tata Hukum Indonesia, Jakarta: Balai Pustaka, p. 119. 
- Waqf deed of pledge / letter endowment pledges made before or since commenced on Government Regulation No. 28 of 1977; or

- Minutes of the auction made by the officials authorized auction, the land has not been recorded; or

- Letter of appointment or purchase a replacement parcel of land taken by the Government or Local Government; or

- Petuk Tax/Landrente, Girik, Pipil, Kekitir and Verponding Indonesia before the enactment of Government Regulation No. 10 of $1961 .^{9}$

Evidence in writing or letter is anything that contains signs reading understandable and contains a certain mind. Signs reading meant for example the Latin alphabet, Arabic alphabet, Kanji and so on. With so everything that does not contain signs reading, or even though the load signs reading but can not understand, it is not included within the meaning of written evidence or a letter. ${ }^{10}$

Viewed from the standpoint of the concept of ownership, it is for those who legally owns the rights to the land, whether registered or not registered may assign its rights to land. Diverting land rights, meaning the transfer of land rights owned by the other parties, with the removal in question, then the right will move. Rights in question, is a legal relationship which is attached as the competent authority or the power to take legal action. In the legal terminology the word "right" means the legal right, or basis for doing something legal action. ${ }^{11}$ Legally, the shift of land rights can be done through several processes, among others:

- Buy and sell;

- Grant;

- Exchange;

- Separation and division of inheritance;

- Submission of grant probate;

- Mortgages;

- Credit verband

Based on the interview with Mr. Sudirman, SH., M.Kn ${ }^{12}$ that there is a conflict which over the years have no end. One of the most frequent land conflicts occur are overlapping cases over a land certificate. Sometimes two certificates even to three or more certificates.

Assistant Chief Ombudsman of the Republic of Indonesia (ORI) Southest Celebes said that the agency most responsible for the administration of land in Kendari is the National Land Agency (BPN) Kendari. Rustan Ahmad said that at this time are very many of the cases reported by the public to relevant Southest Celebes ORI land conflict, be it between the community and the community, and the community and the government. "Today alone we have handled 13 cases related to land issues in several districts in Southeast Celebes" said Rustan expressed. Rustan went on to say that the land issue is being handled by ORI Southest Celebes today is the return of

\footnotetext{
${ }^{9}$ Boedi Harsono, 1997, Hukum Agraria Indonesia, Jakarta: Djambatan, p. 443.

${ }^{10}$ Moh. Taufik Makarao, 2009, Pokok-pokok Hukum Acara Perdata, Jakarta: Rineka Cipta, p. 99

${ }^{11}$ IPM Ranuhandoko, 2000, Terminologi Hukum Inggris-Indonesia, Second Printing, Jakarta: Sinar Graphics, p. 487

${ }^{12}$ According to interviews with Mr. Sudirman, SH., M.Kn as a Notary Public in Kendari, on December 17, 2019, 13:15 pm
} 
Volume 7 Issue 2, June 2020

Nationally Accredited Journal,

Decree No. B/4130/E5/E5.2.1/2019

boundary problems in some areas in Southeast Celebes, among others, Bombana North Buton, Kolaka, Bau-Bau and Kendari. "Besides the issue of the boundary, Southest Celebes ORI is also currently dealing with overlapping issues certificates in Kendari one container port in Bungkutoko land which is still claimed by residents when it had been freed by the City of Kendari", said Rustan. Muhammadiyah University's academics Kendari added that he regretted that the BPN Kendari which he did not order the archiving of files land in Kendari. "The case of overlapping certificate like this could happen because of BPN negligent and disorderly in the office file archiving process, BPN'm always give a reason to the people that it was human error", he added. Through this media, he (read: Ahmad Rustan) trusted the message so the BPN especially the BPN City of Kendari in the inspection the documents which not yet published the certificate on a land, beside it the important thing for the attention of BPN City of Kendari is a literaly process and documentation in the office based on Proceedure Operation Standart (SOP) in the documentation. ${ }^{13}$

Because of law on transfer of rights to land by deed under the hand as evidence in Kendari namely the lack of legal certainty for those who accept the right of the new top soil is concerned, as for a way to resolve that can be taken is to register the transfer of rights to the land to the Land Office.

\subsection{The Weaknesses of Transfer of Rights to Land With Under Hand Deed As Evidence in Kendari}

In order to realize the land administration, land registration is one of the important means. In this case described in Chapter IV General Explanation of the BAL which states: "In accordance with the objective to provide legal certainty, so registration is required for rights holders concerned". Registration for the transfer of land rights stated: "that the registration was made a necessary condition for the entry into force of the third party". ${ }^{14}$

From the discussion previously described, may be understood that the importance of registration of transfer of land rights in order to guarantee legal certainty gained to the recipient rights as holders of such new ground, but on the other hand the importance of the land registry is not always well understood by all parties who make the switch because of land rights due to several factors that become an obstacle.

To know the weaknesses and ensure transfer of rights to land by deed under the hand is as follows: ${ }^{15}$

- Many people who do not transition right before PPAT by frequently switching land rights under the hand (on paper and sealed / sealed).

- The knowledge society is still lacking on the importance of land registration and does not understand the problems and the legal consequences that would be caused in the future.

\footnotetext{
${ }^{13}$ https://faktual.net/tumpang-tindih-sertifikat-tanah-bagian-dari-maladministrasi/\#.XKa7YZgzaUk

${ }^{14}$ Hermanes, 1994, Pendaftaran Tanah Di Indonesia, Jakarta: Yayasan Karya Dharma Institute of the Science of Government, p. 69.

${ }^{15}$ According to interviews with Mr. Sudirman, SH., M.Kn as a Notary Public in Kendari, on December 17, 2019, 13:15 pm
} 
- Problem Building Tax (PBB), among others:

- The amount of land that has no land tax (PBB).

- The process of making Earth Building Tax (PBB) complex / difficult.

- There are still many people who argue with holding the certificate of land (which is still a long in holder name) and / or the deed of transfer of rights made before PPAT is an authentic documentation, so that you no longer need to do the transitional registration of land rights to the Land Office.

- The registration fee transfer of right (behind the name) is fairly high for the community, especially the middle class.

- The registration fee transfer of right (behind the name), which is not transparant.

\subsection{The Solutions of Transition Land Rights With Under Hand Deed As Evidence in Kendari}

Land now has penetrated the complex social issues and require a solution with a comprehensive approach. The development of the nature and substance of the case of land disputes is no longer just a question of land administration which can be resolved through administrative law, but the complexity of the land has penetrated to the realm of the political, social, cultural and related to nationalism and human rights. ${ }^{16}$

Not a few casualties for questioning or maintaining the land only a few square. From year to year, the number of cases in the area of land in Indonesia continues to increase. Within two years, the number of reported cases of National Land Agency (BPN) of the Republic of Indonesia has increased five thousand cases. The lack of transparency in terms of control and ownership of land caused by the limited data and information control and ownership of land, as well as the lack of transparency in the information provided in the community is one of the causes of land disputes. This leads to the concentration of mastery and ownership of land in rural area and / or the number of parcels of land in urban areas, only a small minority of society.

Transition Solutions Land Rights Under the Deed Hand As Evidence Kendari settled by three (3) ways: ${ }^{17}$

- Direct settlement by the parties by agreement

- Through arbitration and alternative dispute resolution

- Judicial dispute resolution

\section{Closing}

\subsection{Conclusion}

Based on the explanation of the description in the previous section, it can be concluded that:

- As a result of the Law On the Transfer of Rights to Land With Under Hand Deeds As Evidence in Kendari namely the absence of legal certainty for those who accept

\footnotetext{
${ }^{16}$ Eko Yulian Isnur, 2012, Tata Cara Mengurus Segala Macam Surat Rumah Dan Tanah, Yogyakarta: Pustaka Yustisia, p. 9

17 According to interviews with Mr. Sudirman, SH., M.Kn as a Notary Public in Kendari, on December 17, 2019, 13:15 pm
} 
Volume 7 Issue 2, June 2020

Nationally Accredited Journal, Decree No. B/4130/E5/E5.2.1/2019

the right of the new top soil is concerned, as for a way to resolve that can be taken is to register the transfer of rights to the land to Land office.

- The weaknesses of Transfer of Rights to Land With Under Hand Deeds As Evidence in Kendari namely the number of people who do not register the transfer of rights or title transfer to the Land Office is the lack of information about the process of the registration of the land, there are many people who make the switch right to land under the hand not in front of PPAT, economic factors, the cost of registration of transfer of rights is fairly high and not transparent, and there are still many who do not own land Earth Building Tax.

- Transition Solutions Land Rights With Under Hand Deeds As Evidence in Kendari, namely Direct settlement by the parties by agreement; Through arbitration and alternative dispute resolution; Settlement of disputes through judicial bodies.

\subsection{Suggestion}

- It is expected that any transfer of land rights must be accompanied by the transfer of rights or registration of title transfer to the Land Office, which is in accordance with applicable regulations, in order to obtain legal certainty as well as the realization of the orderly administration of land, referred to Government Regulation No. 24 of 1997 on Land Registration.

- It is expected that the National Land Agency (BPN) to provide legal counseling on a regular basis to the public about the procedures and requirements for land registration and transparency of the cost required for it.

- The government should have to take a decision that the only institution that takes care of the land administration are the National Land Agency and other agencies just follow the instructions or rules issued by BPN.

\section{References}

[1] Boedi Harsono, 1997, Hukum Agraria Indonesia, Jakarta: Djambatan

[2] 2008, Hukum Agraia Indonesia, Sejarah Pembentukan Undang-Undang Pokok Agraria, Isi dan Pelasanaannya, Jakarta: Djambatan

[3] CST Kansil, 1986, Pengantar IImu Hukum dan Tata Hukum Indonesia, Jakarta: Balai Pustaka

[4] Effendi Perangin, 1994, Hukum Agraria Indonesia, Suatu Telaah Dari Sudut Pandang Praktisi Hukum, Jakarta: King Grafindo Persada

[5] Eko Yulian Isnur, 2012, Procedure for Taking Care of All Kinds Letters Home And Land, Tata Cara Mengurus Segala Macam Surat Rumah Dan Tanah, Yogyakarta: Pustaka Yustisia

[6] Herlien Budiono, 2007, Kumpulan Tulisan Hukum Perdata di Bidang Kenotariatan, Bandung: Citra Aditya Bakti

[7] Hermanes, 1994, Pendaftaran Tanah Di Indonesia, Jakarta: Yayasan Karya Dharma Institute of the Science of Government

[8] https://faktual.net/tumpang-tindih-sertifikat-tanah-bagian-dari-maladministrasi/\#.XKa7YZgzaUk

[9] IPM Ranuhandoko, 2000, Terminologi Hukum Inggris-Indonesia, Second Printing, Jakarta: Sinar Graphics 
[10] J. Kartini Soedjendro, 2001, Perjanjian Peralihan Hak Atas Tanah Yang Berpotensi Konflik, Yogyakarta: Kanisius

[11] Moh. Taufik Makarao, 2009, Pokok-pokok Hukum Acara Perdata, Jakarta: Rineka Cipta

[12] Suharsimi Arikunto, 1990, Manajemen Penelitian, Jakarta: Rineka Cipta

[13] Wantjik Saleh, 1997, Hak Anda atas Tanah, Jakarta: Ghalia Indonesia 